\title{
NÁHRADY ZA OMEZENÍ VÝKONU VLASTNICKÉHO PRÁVA PŘI OCHRANĚ VODNÍCH ZDROJŮ
}

\author{
TEREZA SNOPKOVÁ*
}

\begin{abstract}
Compensation for Ownership Restriction in the Field of Water Resources Protection
The Water Act aims to protect surface and groundwater, to set conditions for the economical use of water resources and to maintain and improve the quality of surface water and groundwater. In accordance with EU law the Water Act creates conditions to reduce the adverse effects of floods and droughts and to ensure the safety of water plants. It also aims to support the drinking water supply system and protect aquatic ecosystems. While surface water and groundwater is not an object of property under the Czech law, the land on which or under which water exists is a part of individual property. Owning of the land is limited by the public interest on the quantity and quality of the water. The protection of water resources creates a conflict between the right of ownership and the right to a favourable environment (water protection). In a particular case, consideration should be given to the comparison of the owner-constraint versus importance of an object of public interest - water protection. The owner-constraint must be reasonable and desirable. At a time when significant climate change is taking place and the value of water is becoming increasingly important, this issue needs to be addressed intensively. In this context, the issue of compensation for owners' limitations in the protection of water resources is becoming increasingly important. This paper deals in general with the relation between property (individual) rights and environmental protection (public interest). It deals with a specific restriction within the exercise of property rights in favor of protective zones of water resources and with the possible compensations for these limitations.
\end{abstract}

Keywords: water resource; ownership; protection zone; restrictions of rights to property; compensations

Klíčová slova: vodní zdroj; vlastnické právo; ochranné pásmo; omezení vlastnického práva; náhrady

DOI: $10.14712 / 23366478.2019 .27$

\footnotetext{
* Autorka je absolventkou Právnické fakulty Univerzity Karlovy a Fulbrightova programu, je členkou České společnosti pro právo životního prostředí.
} 


\section{VLASTNICKÉ PRÁVO A OCHRANA VEŘEJNÝCH STATKU゚ (ŽIVOTNÍHO PROSTŘEDÍ)}

\subsection{POVAHA VLASTNICKÉHO PRÁVA}

Ochranu vlastnického práva zaručuje Listina základních práv a svobod ve svém článku 11: „Každý má právo vlastnit majetek a vlastnické právo všech vlastníků má stejný zákonný obsah a ochranu. "Vlastnické právo však není neomezené. Již článek 11 odst. 3 Listiny základních práv a svobod upravuje meze výkonu vlastnického práva: „Vlastnictví nesmí být zneužito na újmu práv druhých anebo v rozporu se zákonem chráněnými obecnými zájmy. Jeho výkon nesmí poškozovat lidské zdraví, prírodu a životní prostředi nad míru stanovenou zákonem." Zde uvedená omezení zavazují vlastníka vůči určitým hodnotám, jejichž ochrana je v zájmu veřejnosti.

K možnostem omezení vlastnického práva se opakovaně vyjadřují nejvyšší soudy České republiky. Vlastnické právo nelze chápat jako absolutně neomezené právo, naopak, omezení se připouští již ve výše uvedeném čl. 11 odst. 3 Listiny základních práv a svobod. S tím však souvisí požadavek na poměřování zásahu do základního - vlastnického práva ve prospěch ochrany veřejného statku. Musí jít o legitimní cíl a musí být zachována přiměřenost. $\mathrm{V}$ některých př́padech je zákonodárce $\mathrm{k}$ takové úpravě (omezení základního práva nebo svobody) výslovně zmocněn.

„Ústavni prostor tohoto postupu zákonodárce je přitom určen požadavkem šetření podstaty a smyslu omezovaného nebo vymezovaného základního práva, resp. svobody (čl. 4 odst. 4 Listiny základních práv a svobod). K omezení základnich práv či svobod, i když jejich ústavní úprava omezení nepředpokládá, může dojit v př́padě jejich kolize nebo v př́padě kolize s jinou ústavně chráněnou hodnotou, jež nemá povahu základního práva a svobody (veřejný statek)."1

Pro případ překročení přiměřenosti omezení vlastnického práva podle čl. 11 odst. 3 Listiny základních práv a svobod, kde jde o tzv. vnitřní omezení (jedná se o omezení, které se vztahuje na obecně vymezený okruh adresátů), ${ }^{2}$ lze zvažovat omezení další. Je-li ve veřejném zájmu nezbytné další (širší) omezení vlastnického práva, je na místě využít ustanovení čl. 11 odst. 4 Listiny základních práva a svobod, které stanoví, že „Vyvlastnění nebo nucené omezení vlastnického práva je možné ve veřejném zájmu, a to na základè zákona a za náhradu.“

Vzhledem k tomu, že omezení dle článku 11 odst. 4 Listiny základních práv a svobod přesahují samotné vnitřní meze výkonu vlastnického práva (v důsledku vnějšího zásahu do vlastnického práva dochází k jeho zúžení), je nezbytné toto omezení nahradit.

$\mathrm{K}$ přiměřenosti vnějších opatření ${ }^{3}$ a nutnosti proporcionality mezi použitými prostředky a sledovanými cíli Ústavní soud v obecné rovině uvedl, že je nutno vždy po-

\footnotetext{
Nález Ústavního soudu ze dne 9. 10. 1996, sp. zn. I. ÚS 15/96.

2 Viz KOCOUREK, T. Omezení vlastnického práva k pozemkům ve prospěch ochraně životního prostredí. Praha: Leges, 2012, s. 20-21; BALOUNOVẢ, J. Chráněná území jako institut omezující vlastnické právo. Právní rozhledy [online], 2018, č. 6, s. 197. Dostupné na: https://www.beck-online.cz, 3. 4. 2019.

3 Za vnější omezení je třeba považovat ta omezení, která překračují vnitřní meze výkonu vlastnického práva. Důsledkem vnějšího omezení vlastnického práva je jeho zúžení, které vytváríi nerovnost mezi vlastníky, proto je třeba zvažovat kompenzaci. Viz též JANČÁŘOVÁ, I. a kol. Právo životního prostředi: obecná
} 
drobně posoudit existenci veřejného zájmu, který opravňuje k uplatnění omezujících opatření vůči soukromým osobám. „Zasahování státu musí respektovat přiměřenou (spravedlivou) rovnováhu mezi požadavkem obecného zájmu společnosti a požadavkem na ochranu základních práv jednotlivce. To znamená, že musí existovat rozumný (opodstatněný) vztah proporcionality mezi použitými prostředky a sledovanými cíli.“" $\mathrm{Ne}$ odůvodněné a nepřiměřené omezení práv jednotlivců by bylo porušením s čl. 4 odst. 4 Listiny základních práv a svobod. Podle tohoto ustanovení musí být při používání ustanovení o mezích základních práv a svobod šetřeno jejich podstaty a smyslu a omezení nesmějí být zneuživána $\mathrm{k}$ jiným účelům, než pro které byla stanovena.

Lze tedy konstatovat, že zákon může obecně omezit vlastnické právo, aniž by za to stanovil náhradu, ovšem ustanovení čl. 11 odst. 4 Listiny základních práv a svobod se bude vztahovat na kvalifikované př́ípady omezení, tj. prŕípady, kdy omezení jde nad rámec povinností, která mají všichni ostatní vlastníci, tj. tam, kde není zachována rovnost.

Omezení vlastnického práva kromě toho musí být přiměřené sledovanému účelu a reflektovat podstatu a smysl vlastnického práva.

\subsection{OMEZENÍ VLASTNICKÉHO PRÁVA Z DƯVODU OCHRANY ŽIVOTNÍHO PROSTŘEDÍ}

Ústavní soud vymezil též kritéria pro určení možného omezení základního práva či svobody ve prospěch ochrany životního prostředí. ${ }^{5}$ Jedním z důvodů omezení vlastnického práva je právě ochrana životního prostředí (a to již v článku 11 odst. 3 Listiny základních práv a svobod). Článek 7 Ústavy České republiky, v němž se stanoví, že ,stát dbá o šetrné využivání prírodnich zdrojů a ochranu prírodního bohat$s t v i$ “, obecně vymezuje veřejný zájem na ochraně životního prostředí. Přestože nejde o výslovné označení ochrany životního prostředí jako veřejného zájmu, lze s ohledem na celospolečenskou prospěšnost této ochrany veřejný zájem, resp. povahu životního prostředí jako veřejného statku, dovodit. S odkazem na nález Ústavního soudu ze dne 9. 10. 1996, sp. zn. I. ÚS 15/96 lze připomenout, že vymezením veřejného statku se určuje určitá hodnota, která není přidělitelná pouze jednotlivci, naopak jde o zájem, který je nedělitelný a svědčí všem osobám.

„Ústavni úprava postaveni jedince ve společnosti obsahuje ochranu individuálnich práv a svobod, jakož i ochranu veřejných statkủ. Rozdil mezi nimi spočívá v jejich distributivnosti. Pro verejné statky je typické, že prospěch z nich je nedèlitelný a lidé nemohou být vyloučeni z jeho poživání. Př́klady veřejných statkư jsou národni bezpečnost, veřejný pořádek, zdravé životni prostředí. Veřejným statkem se tudiž určitý aspekt lidské existence stává za podmínky, kdy není možno jej pojmově, věcně i právně rozložit na části a tyto priřadit jednotlivcuim jako podily.“

část. Brno: Masarykova univerzita, Právnická fakulta, 2016, s. 175 a 177. Nutno dodat, že v praxi se rozdíly mezi odstavcem 3 a 4 článku 11 Listiny základních práv a svobod, tedy mezi vnějším a vnitřním omezením často stírají, a je třeba vždy v konkrétním případě posoudit intenzitu omezení a dopad na vlastnické právo.

4 Nález Ústavního soudu ze dne 16. 10. 2001, sp. zn. P1. ÚS 5/01.

5 Nález Ústavního soudu ze dne 9. 10. 1996, sp. zn. I. ÚS 15/96. 
Kritéria řešení kolize mezi ochranou soukromého práva a veřejného statku spočívají podle Ústavního soudu v posuzování vhodnosti (zda omezení základního práva či svobody povede ke sledovanému cíli), potřebnosti (zda je nezbytné řešit kolizi zájmů cestou omezení základního práva) a v porovnání závažnosti zájmů, které jsou v kolizi. ${ }^{6}$

Vymezením veřejného zájmu (ve vztahu k ochraně životního prostředí) se podrobněji zabývá odborná literatura, např. citované dílo Tomáše Kocourka ${ }^{7}$ nebo dílo Jakuba Hanáka. ${ }^{8}$

K řešení kolize mezi soukromým a veřejným zájmem lze doplnit, že omezující opatření k environmentálním účelům se někdy mohou týkat zájmů pouze omezeného množství vlastníků, tudíž nepůjde o poměřování celospolečenského opatření s vlastnickým právem omezovaných vlastníků. Omezení, resp. náhrady za něj však budou i v tomto př́padě vázány na veřejný zájem.

\section{OCHRANNÁ PÁSMA K OCHRANĚ VODNÍCH ZDROJU゚}

Vodním zdrojem jsou podle ustanovení § 2 odst. 8 vodního zákona povrchové nebo podzemní vody, které jsou využivány nebo které mohou být využívány pro uspokojení potřeb člověka, zejména pro pitné účely.

K ochraně vodních zdrojů slouží ochranná pásma. Ochranné pásmo je vymezeno jako určité území v okolí objektu, jehož smyslem je ochrana objektu před negativními vlivy okolí. Pro ochranné pásmo je typické, že se v něm zakazují nebo omezují určité činnosti z důvodu veřejného zájmu na ochraně objektu, $\mathrm{k}$ němuž se ochranné pásmo vztahuje. ${ }^{9}$ Existence ochranného pásma může vyplývat ze zákona nebo z podzákonného právního předpisu, ochranná pásma vodních zdrojů jsou vyhlašována opatřením obecné povahy.

„Ochranná pásma slouži k ochraně vydatnosti, jakosti a zdravotni nezávadnosti zdrojů podzemnich nebo povrchových vod využivaných nebo využitelných pro zásobování pitnou vodou s prüměrným odběrem více než $10000 \mathrm{~m}^{3}$ za rok a zdrojů podzemní vody pro výrobu balené kojenecké vody nebo pramenité vody, popr.s. s ohledem na závažné okolnosti i k ochraně vodnich zdrojů s nižši kapacitou." "10

Vodní zákon výslovně uvádí, že stanovení ochranných pásem je vždy veřejným zájmem. ${ }^{11}$

„Ochranná pásma se dèlí na ochranná pásma I. stupně, která slouži k ochraně vodního zdroje $v$ bezprostředním okoli jímacího nebo odběrného zařizení, a ochranná pásma II. stupnè, která slouži k ochraně vodního zdroje v územích stanovených vodoprávním úradem tak, aby nedocházelo $k$ ohrožení jeho vydatnosti, jakosti nebo

\footnotetext{
${ }^{6}$ Zde je též zvažována závažnost či míra prostředků užitých k omezení vlastnického práva.

7 KOCOUREK, T. Omezení vlastnického práva k pozemki̊m ve prospěch ochraně životního prostředí. Praha: Leges, 2012, s. 23-27.

8 HANÁK, J. Vyvlastnění z environmentálních dưvodi̊: současný stav a perspektivy. Brno: Masarykova univerzita, 2015. Spisy Právnické fakulty MU č. 536 (Edice Scientia), s. 77 a násl.

9 Nejvyšší soud, 22 Cdo 1022/2014, [C 15491].

10 Ustanovení § 30 odst. 1 vodního zákona.

11 Ustanovení § 30 odst. 1 vodního zákona, poslední věta.
} 
zdravotní nezávadnosti."12 Vodní zákon dále specifikuje způsob, resp. rozsah vymezení ochranného pásma.

Ochranná pásma vodních zdrojů se vyhlašují na návrh nebo z vlastního podnětu, přičemž, odpadne-li důvod ochrany, vodoprávní úrad ochranné pásmo opatřením obecné povahy zruší.

Podle ustanovení $§ 30$ odst. 10 vodního zákona vodoprávní úřad v opatření obecné povahy stanoví, které činnosti poškozující nebo ohrožující vydatnost, jakost nebo zdravotní nezávadnost vodního zdroje nelze v tomto pásmu provádět, jaká technická opatření jsou v ochranném pásmu povinny provést osoby podle odstavce 12 , popř́padě způsob a dobu omezení užívání pozemků a staveb v tomto pásmu ležících.

\section{K POSKYTNUTÍ NÁHRADY ZA OMEZENÍ VLASTNICKÉHO PRÁVA Z DƯVODU VYHLÁŠENÍ OCHRANNÉHO PÁSMA}

Otázku náhrady za omezení ochranným pásmem je třeba zkoumat jednak v obecné rovině. Dále je třeba ji zkoumat na základě speciálního ustanovení ve vodním zákoně a aplikovat ji na konkrétní situaci.

Obecně lze konstatovat, že v př́padě, kdyby omezení vlastníka pozemku zatíženého ve veřejném zájmu ochranným pásmem dosáhla takové intenzity, že by byla zasažena samotná podstata vlastnictví, vlastníkovi by náležela náhrada za omezení vlastnického práva. Nárok na náhradu za omezení vlastnického práva nevzniká tedy v případě jakéhokoli omezení vlastnického práva, ale pouze v př́ípadě, kdy omezení dosáhne určité intenzity.

Ústavní soud v nálezu III. ÚS 950/17 s odkazem na předchozí judikaturu uvedl, že v praxi existují situace, kdy k omezení vlastnického práva dochází, ale není nezbytné za předmětné omezení poskytnout náhradu. „Vyvlastněním či omezením vlastnického práva je třeba rozumět pouze takové omezení, které vylučuje realizaci vlastnického práva bud' zcela, nebo v rozsahu, který podstatnou měrou znemožňuje výkon vlastnického práva v některé z jeho složek."13

Vyhlášením ochranného pásma, resp. omezeními v něm stanovenými, k omezení vlastnického práva dochází, proto je třeba v obecné rovině uvažovat o tom, že vlastníkovi za omezení jeho vlastnického práva náleží náhrada podle čl. 11 odst. 4 Listiny. ${ }^{14}$

S ohledem na omezení, která existence ochranného pásma vodního zdroj přináší, se jedná o územní omezení majetkových práv. ${ }^{15}$ Je tedy na místě zvažovat dopad ustanovení čl. 11 odst. 3 , resp. 4 Listiny základních práv a svobod.

Ve věci poskytnutí náhrady lze z praktických prŕikladů odkázat na rozhodnutí Nejvyššího soudu 22 Cdo 1022/2014, [C 15491]. Ve věci možné náhrady za omezení vlastnic-

12 Princip dvoupásmové ochrany a další principy blíže popisuje např. např. STRNAD, Z. a kol. Vodní právo. Vodňany: Jihočeská univerzita v Českých Budějovicích, Fakulta rybářství a ochrany vod, 2015, s. 123 a 124.

13 Nález III. ÚS 950/17 ve spojení s nálezem ÚS z 13. 12. 2006, sp. zn. Pl. ÚS 34/03, č. 49/2007 Sb.

14 Nejvyšší soud, 22 Cdo 1022/2014, [C 15491].

15 HENDRYCH, D. a kol. Správní právo. Obecní ćást. 8. vydání. Praha: C. H. Beck, 2012, 826 s. Dostupné na: https://www.beck-online.cz, 9. 6. 2019. 
kého práva dovolatelky, která vlastnila pozemek v ochranném pásmu letiště leteckých staveb, Nejvyšší soud konstatoval omezení vlastnického práva z důvodu ochranného pásma a uvedl $\mathrm{k}$ tomu několik podstatných závěrů.

Prvně uvedl, že stanovení přiměrené náhrady za omezení vlastnického práva není podle čl. 11 odst. 4 Listiny otázkou skutkovou, nýbrž se jedná o otázku právní, náhrada tedy musí být stanovena úvahou soudu, a musí zahrnout konkrétní okolnosti př́padu, zejm. rozsah omezení vlastníka či dosavadní a plánované využití pozemku, popř. to, jak dlouho ochranné pásmo trvá.

Z tohoto lze dovodit, že vlastník, který je ochranným pásmem omezen v užívání předmětu vlastnictví, se může vždy dovolávat náhrady za omezení vlastnického práva.

Předpokladem pro náhradu je to, že vlastnické právo je omezeno nad spravedlivou míru. Je tedy třeba vyhodnotit, „zda po vlastníkovi, který je omezen na svém vlastnickém právu z di̊vodu existence ochranného pásma a jemuž z přislušného zákona výslovně nevyplývá nárok na náhradu za omezení vlastnického práva, lze ještě spravedlivě požadovat, aby strpèl omezeni svého vlastnického práva způsobené existencí ochranného pásma bez náhrady, nebo zda je třeba mu priznat náhradu za omezení vlastnického práva ochranným pásmem, a to na základě prrimé aplikace čl. 11 odst. 4 Listiny“. ${ }^{16}$

Nejvyšší soud uvedl, že lze přihlédnout napríílad i k tomu, za jakých podmínek vlastník pozemek nabyl, a zda již v okamžiku nabytí ochranné pásmo existovalo. Současně však uvedl, že náhradu za omezení vlastnického práva nelze zcela odeprít jen $\mathrm{z}$ toho důvodu, že při koupi byl pozemek ochranným pásmem již omezen. ${ }^{17}$

Konečně Nejvyšší soud uvedl, že ,pasivni věcná legitimace $k$ náhradě za omezení vlastnického práva podle čl. 11 odst. 4 Listiny z důvodu existence ochranného pásma je odvislá od toho, zda ochranné pásmo existuje toliko $k$ ochraně verejného zájmu, aniž by z jeho zřizení profitoval konkrétní subjekt, či zda je ochranné pásmo sice zř́zeno veřejnoprávními předpisy k ochraně veřejného zájmu, ale slouži k tvorbě zisku či ke garanci uživacich práv osoby, v jejiž prospěch je zřizeno. V prve uvedeném prípadě bude pasivně věcně legitimovaným stát, ve druhém př́padě bude pasivně věcně legitimovanou osoba, v jejiž prospěch bylo ochranné pásmo zřizeno či v jejiž prospěch ochranné pásmo slouží.“

Z další judikatury považuji za vhodné odkázat na další případy, kdy dochází k omezení vlastnického práva ve vztahu k určitému území (jinému, než je zřízení ochranného pásma), a to $\mathrm{z}$ toho důvodu, že v nich soudy vymezily podstatné důvody pro přiznání náhrady.

Ústavní soud ve věci dopadu opatření obecné povahy vymezujícího územní rezervu řešil, zda vlastníkovi pozemku zahrnutého v územní rezervě př́sluší náhrada za omezení vlastnického práva. ${ }^{18}$ Ústavní soud zde došel k závěru, že poskytnutí náhrady se musí vždy odvíjet od okolností konkrétního príípadu. Je třeba zkoumat, jaké konkrétní omeze-

16 Nejvyšší soud, 22 Cdo 1022/2014, [C 15491].

17 Autoři brněnské učebnice práva životního prostředí se domnívají, že náhrada za omezení, která existovala již v době nabytí stavby či pozemku, v zásadě nepřísluší. Přísluší však v případě změny v pokračujícím užívání. Vždy je však třeba vzít v úvahu snížení ceny pozemku v ochranném pásmu vodního zdroje. Viz JANČÁŘOVÁ, I. a kol. Právo životního prostředi: obecná část. Brno: Masarykova univerzita, Právnická fakulta, 2016, s. 178.

18 Nález Ústavního soudu III. ÚS 950/17. 
ní územní rezerva představuje pro konkrétního vlastníka a dále též, jaká je délka tohoto omezení. Nelze tedy apriori předjímat, že ,územní rezerva nemůže nikdy představovat zásah do vlastnického práva, který by bylo třeba nahradit dle čl. 11 odst. 4 Listiny“. Důležitým kritériem je $\mathrm{v}$ tomto případě posouzení konkrétního př́ipadu a zohlednění omezení ve vztahu k časové ose.

V nálezu IV. ÚS 652/06 ze dne 19. 12. 2007 se Ústavní soud zabýval náhradou za omezení § 60 odst. 1 vodního zákona. Podle tohoto ustanovení vodního zákona platí: „Vlastníci pozemki̊ sousedících s vodním dílem jsou povinni po predchozím projednání s nimi umožnit za účelem provozu a provádění údržby vodních děl v nezbytném rozsahu vstup a vjezd na své pozemky těm, kteři zajištují provoz nebo prováději údržbu těchto vodnich děl."

Ústavní soud zde dovodil, že výše uvedený vstup a vjezd na pozemky omezuje vlastnické právo. Nelze tedy vyloučit náhradu za toto omezení. Ostatně, ani vodní zákon tuto náhradu výslovně nevylučuje. Omezení vlastnického práva je podle Ústavního soudu v případě ustanovení $\S 60$ odst. 1 vodního zákona ve veřejném zájmu, a to s ohledem na vazbu na provoz a údržbu vodních děl jako zařízení plnících zájem na ochraně životního prostředí. Současně bylo konstatováno, že náhrada je o to více nutná, když provoz vodní elektrárny je podnikatelskou činností, nikoliv správou veřejného statku.

Důležitým kritériem pro přiznání náhrady v tomto př́ípadě bylo vymezení subjektu, který profituje z daného omezení, což je využitelné i při využívání vodního zdroje, k jehož ochraně je ochranné pásmo stanoveno. ${ }^{19}$

\section{K POSKYTNUTÍ NÁHRADY ZA OMEZENÍ OCHRANNÝM PÁSMEM VODNÍHO ZDROJE}

Jak je uvedeno výše, vodní zákon označuje stanovení ochranných pásem za veřejný zájem. Tímto je naplněna první podmínka omezení vlastnického práva podle Listiny základních práv a svobod, tj. že omezení je možné pouze ve veřejném zájmu.

Druhá podmínka, že omezení musí být provedeno na základě zákona, je naplněna ustanovením $\S 30$ odst. 1 a následujícími vodního zákona. Opatření obecné povahy, jímž se ochranné pásmo vodního zdroje vyhlašuje, je vydáváno na základě ustanovení vodního zákona.

Třetí otázkou je posouzení míry zásahu do vlastnického práva. V tomto kroku jde o zkoumání toho, zda se jedná o zásah takový, že zasahuje př́mo do podstaty vlastnictví. S ohledem na výše uvedené, lze konstatovat, že existence ochranného pásma vodního zdroje jakožto územního omezení majetkových práv ${ }^{20}$ je omezením vlastnického práva, za které přísluší poskytnutí náhrady.

V př́ípadě vyhlášení ochranných pásem vodních zdrojů zákonodárce sám seznal, že náhrada je nezbytná. Proto vložil do vodního zákona výslovné ustanovení o náhradě. V ustanovení § 30 odst. 11 se uvádí, že „Za prokázané omezení užívání pozem-

19 Tímto byl potvrzen princip uvedený výše v rozhodnutí Nejvyššího soudu 22 Cdo 1022/2014.

20 HENDRYCH, D. a kol. Správní právo. Obecní část [online]. 8. vydání. Praha: C. H. Beck, 2012, $826 \mathrm{~s}$. Dostupné na: https://www.beck-online.cz, 3. 4. 2019. 
ků a staveb v ochranných pásmech vodních zdrojů náleži vlastníkům nebo nájemcům nebo pachtýrùm těchto pozemků a staveb náhrada, kterou jsou povinni na jejich žádost poskytnout v př́padě vodárenských nádrži vlastnici vodnich děl umožňujicich v nich vzdouváni vody, v ostatnich př́padech oprávněni (\$ 8) k odběru vody z vodního zdroje; je-li jich více, pomèrně podle povoleného množství odebírané vody. Nedojde-li o poskytnutí náhrady $k$ dohodě, rozhodne o jednorázové náhradě soud." Citované ustanovení kromě jiného odpovídá výše uvedeným závěrům Nejvyššího soudu ve věci pasivně legitimovaného subjektu povinného $\mathrm{k}$ náhradě. ${ }^{21}$

$\mathrm{V}$ rámci aplikace citovaného ustanovení vodního zákona však bude třeba posoudit limity poskytnutí náhrady. Poskytnutí náhrady je zde vázáno na „prokázané omezení uživání pozemků a staveb v ochranných pásmech vodnich zdrojü“.

S ohledem na výše uvedená kritéria dovozená judikaturou nejvyšších soudů by měla být brána $\mathrm{v}$ potaz nejen omezení daná současným využitím pozemku, ale príípadně také jeho plánovaným využitím.

Pro poskytnutí náhrady nebude podstatné to (nebo jediné posuzované), zda vlastník pozemek nabyl již s omezeným využiváním nebo k omezení došlo až v průběhu existence jeho vlastnického práva.

Pokud jde o další návodné postupy, je možné vzít v úvahu Metodický pokyn Ministerstva zemědělství ze dne 10. 12. 2004 (dále jen „Metodický pokyn MZe“).22

Metodický pokyn MZe upřesňuje, že náhrady podle vodního zákona nelze vztáhnout na omezení vlastnického práva, která vyplývají ze zvláštních právních předpisů, např. ze zákona o ochraně přírody a krajiny nebo ze zákona o zemědělském půdním fondu a další (viz čl. 1 odst. 3 Metodického pokynu MZe).

Metodický pokyn MZe se vztahuje pouze na postupy státních podniků Povodí. Je-li tedy vlastníkem nebo „oprávněným“ uvedeným v $§ 30$ odst. 11 vodního zákona někdo jiný než Povodí, pak se bude postupovat pouze podle zákonných ustanovení.

Ostatně metodický pokyn má pouze vnitřní závaznost a jeho naplnění nemusí odpovídat rozsahu skutečné náhrady, jak by ji př́padně stanovil soud (viz dále).

Náhrady podle ustanovení $§ 30$ odst. 9 vodního zákona nelze poskytnout za jiná omezení nebo povinnosti dané jinými ustanoveními vodního zákona mimo ustanovení o vyhlášení ochranných pásem vodních zdrojů.

Podle článku 1 odst. 2 Metodického pokynu MZe má být náhrada vyplacena ,po splnění podminek dále uvedených v tomto metodickém pokynu“.

Pro účely žádosti o náhradu je v souladu s Metodickým pokynem MZe nezbytné uvést „výčet jednotlivých omezení vyplývajicich pro žadatele z rozhodnutí o stanovení nebo o změně ochranných pásem vodárenských nádrži“ a dále ,porovnání pưvodního způsobu hospodaření s hospodařením podle omezujicich podmínek včetně návrhu výše požadované úhrady“.

Předpokládá se tedy, že náhrada je vázána na změnu hospodaření na pozemku.

21 Viz rozsudek Nejvyššího soudu, 22 Cdo 1022/2014, [C 15491].

22 Č. j. 43656/2004-16000 Metodický pokyn k postupu státních podniků Povodí při poskytování náhrad za omezení užívání nemovitostí v ochranných pásmech vodních zdrojů dle $§ 30$ odst. 9 zákona č. 254/2001 Sb., o vodách a o změně některých zákonů (vodní zákon), ve znění pozdějších předpisů. 
Povodí posoudí žádost, a pokud uzná náhradu, stanoví splátkový kalendáŕ, dohodu o výkonu práv, př́ípadně další ujednání.

Pokud žadatel není u Povodí úspěšný, musí se v souladu s $§ 30$ odst. 11 vodního zákona obrátit na soud: „Nedojde-li o poskytnutí náhrady k dohodě, rozhodne o jednorázové náhradě soud."

Nicméně ustanovení vodního zákona je širší a vztahuje se na omezení „za uživání pozemků a staveb“, tj. nejen na změnu hospodaření, o níž se zmiňuje Metodický pokyn MZe.

Přitom veškerá omezení, která plynou vlastníkům dotčeným vyhlášením ochranného pásma, zcela jistě představují omezení, která posouzení náhrady vyžadují.

Pro ochranné pásmo I. stupně platí zákaz vstupu a vjezdu (mimo osoby, které mají právo vodu z vodního zdroje odebírat, a u vodárenských nádrží pro osoby, které tato vodní díla vlastní). Další výjimky z tohoto zákazu může stanovit vodoprávní úřad.

Podle $\S 30$ odst. 8 vodního zákona je v ochranném pásmu I. a II. stupně zakázáno provádět činnosti poškozující nebo ohrožující vydatnost, jakost nebo zdravotní nezávadnost vodního zdroje, jejichž rozsah je vymezen v opatření obecné povahy o stanovení nebo změně ochranného pásma.

Konkretizace omezení je tedy dána opatřením obecné povahy, kterým se ochranné pásmo vyhlašuje. Připomínám ustanovení $\S 30$ odst. 10 vodního zákona, podle něhož vodoprávní úřad $\mathrm{v}$ opatření obecné povahy stanoví, které činnosti poškozující nebo ohrožující vydatnost, jakost nebo zdravotní nezávadnost vodního zdroje nelze v tomto pásmu provádět.

Kombinace zákazu vjezdu a vstupu (vč. výjimek) a omezení činností s negativním dopadem na vodní zdroj umožní Povodí, resp. soudu stanovit míru omezení a v návaznosti na to na výši náhrad za omezení vlastnického práva.

Pokud bychom dospěli k závěru, že náhrada má být poskytnuta pouze za omezení, která jsou výslovně uvedena ve vodním zákoně (zákaz vstupu a vjezdu do ochranného pásma I. stupně podle $\S 30$ odst. 7 vodního zákona) nebo v opatření obecné povahy, kterým se vyhlašuje ochranné pásmo, pak by mohla být vyloučena náhrada za možná další omezení, která by ale odpovídala závěrům judikatury, tj. byla by „nespravedlivým zásahem do vlastnického práva", který vyžaduje náhradu. I u těchto dalších omezení by bylo nutno zkoumat intenzitu omezení vlastnického práva a z toho dovodit, zda v konkrétním př́ípadě př́sluší náhrada či nikoliv. ${ }^{23}$

Konkrétním př́ípadem z praxe může být nemožnost vlastníka rodinného domu využít řešení nakládání $\mathrm{s}$ odpadními vodami způsobem uvedeným $\mathrm{v} \S 38$ odst. 9 vodního zákona. Jde o možnost vodoprávního úřadu povolit vypouštění přečištěných odpadních vod přes půdní vrstvy do vod podzemních. Jedná se o výjimečnou možnost vázanou pouze na specifické př́ípady, která vyžaduje kladné vyjádření odborně způsobilé osoby. Předmětné povolení v zásadě nemůže být vydáno, pokud by mělo dojít $\mathrm{k}$ ohrožení podzemních vod.

23 Zde se ztotožňuji se závěry JUDr. Balounové, která dovozuje náhradu za omezení vlastnického práva pro chráněná území ve srovnání s náhradou za omezení v ochranných pásmech: BALOUNOVÁ, J. Chráněná území jako institut omezující vlastnické právo. Právní rozhledy [online], 2018, č. 6, s. 197 a násl. Dostupné na: https://www.beck-online.cz, 3. 4. 2019. 
Je-li důvodem zamítnutí tohoto způsobu nakládání s odpadními vodami to, že se objekt nachází v ochranném pásmu vodního zdroje, pročež jsou k ochraně blízkého vodního zdroje určeného jako zdroj pitné vody uplatněna př́snější kritéria (princip předběžné opatrnosti), pak se jedná o omezení, které spadá do okruhu omezení vyžadujících náhradu. Lze proto zvažovat uplatnění tohoto nároku v souladu s vodním zákonem u Povodí či jiného subjektu, popř. u soudu. Bude-li prokázána dostatečná intenzita omezení vlastnického práva $\mathrm{v}$ tomto směru (ve smyslu nemožnosti volit způsob nakládání s odpadními vodami), měl by být přiznán nárok na náhradu. Tento nárok lze uplatnit i v př́ípadě, že uvedené omezení není výslovně vyjmenováno ve vodním zákoně ani v opatření obecné povahy, kterým bylo vyhlášeno ochranné pásmo.

\section{ZÁVĚR}

$\mathrm{S}$ ohledem na změny, které $\mathrm{v}$ krajině $\mathrm{v}$ důsledku klimatických změn probíhají, lze očekávat, že vodní zdroje budou vyžadovat přísnější ochranu. S přísnější ochranou souvisí též další možné náhrady za omezení vlastnického práva. V souladu s hodnotami a limity, které stanoví ústavní předpisy České republiky, nelze spravedlivě požadovat, aby jeden vlastník byl ve výkonu svého vlastnického práva bez náhrady omezen více než jiný vlastník, směřuje-li dané omezení $\mathrm{k}$ ochraně veřejného zájmu.

Ochrana vodních zdrojů včetně stanovení ochranných pásem je veřejným zájmem. Je proto nezbytné aplikovat ustanovení o náhradách a tyto náhrady vždy zvažovat. V každém konkrétním př́ipadě pak musí být posuzováno konkrétní dotčení vlastnického práva, intenzita jeho omezení a vliv tohoto omezení na samotnou podstatu vlastnického práva.

Jestliže součástí vlastnického práva je oprávnění věc uživat, pak změna užívání, resp. omezení tohoto užívání pouze na určité způsoby, představuje omezení, které je třeba nahradit. V řízení o náhradě bude třeba zvažovat kromě jiného to, do jaké míry lze vlastníkovi přičítat to, že předmět vlastnictví nabyl již s omezením.

Závěrem je třeba konstatovat, že vodní zákon výslovně přiznává náhrady za omezení vlastnického práva $\mathrm{v}$ ochranných pásmech vodních zdrojů. Tím vytváří základní rámec pro vyvážení veřejného zájmu na ochraně vody a soukromých zájmů vlastníků.

Do budoucna je třeba zvažovat, zda náhrady budou poskytovány neomezeně za jakoukoliv omezenou činnost vlastníka, nebo zda (a jak) bude rozlišována činnost nezbytná pro jednotlivce a činnost podnikatelská.

Ochrana vody, resp. vodních zdrojů představuje nyní výzvu zejména v koncepční rovině. Řádné koncepční a ruku v ruce s tím praktické řešení vodního cyklu v krajině by mělo umožnit nastavit pravidla pro řešení střetu veřejného a soukromého zájmu udržitelným způsobem, a to jak z hlediska ekonomického, tak z hlediska lidskoprávního.

JUDr. Tereza Snopková, Ph.D.

Česká společnost pro právo životního prostředí, z. s.

tereza.snopkova@gmail.com 